\title{
PPP2R5E wt Allele
}

National Cancer Institute

\section{Source}

National Cancer Institute. PPP2R5E wt Allele. NCI Thesaurus. Code C49448.

Human PPP2R5E wild-type allele is located in the vicinity of 14q23.1 and is approximately $169 \mathrm{~kb}$ in leng th. This allele, which encodes serine/threonine-protein phosphatase 2A 56 $\mathrm{kDa}$ regulatory subunit epsilon isoform protein, plays a role in modulating both the substrate selectivity and catalytic activity of the core protein phosphatase $2 \mathrm{~A}$ heterodimer. 